\title{
FORECASTING THE SITUATION IN THE FINANCIAL MARKET AND EVALUATING ITS IMPACT ON THE INDUSTRY DEVELOPMENT
}

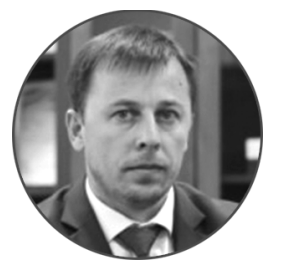

Ruslan Kh. IL'YASOV

Chechen State University, Grozny, Chechen Republic, Russian Federation

ilyasov_95@mail.ru

Corresponding author

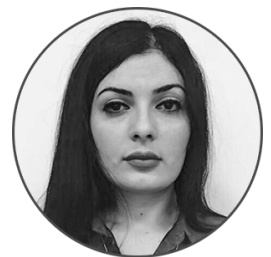

\section{Diana A. KURAZOVA}

Chechen State University, Grozny, Chechen Republic, Russian Federation diana.kurazova.89@list.ru

\section{Article history:}

Received 29 August 2017

Received in revised form

2 October 2017

Accepted 23 October 2017

Translated 26 January 2018

Available online 27 March 2018

JEL classification: G12, G32

Keywords: financial market, industry, financial market indicators, market conditions

\begin{abstract}
Importance The research focuses on mathematical methods for forecasting the financial market trends in its impact on the industry development. Viewing the future economic development through the lens of the financial sector trends, many researchers proved the relationship between the financial market situation and the industrial sector.

Objectives In theory and practice, the research substantiates the significance of the financial market, its impact of the real economy, considering the existing lack of finance and investment resources. Applying mathematical tools for analyzing the market and its future trends, we determine how it will rise and fall in industrial sectors of the national economy. The forecast allows to adjust an economic policy and alleviate possible crunches.

Methods Based on methods of regression-and-correlation, statistical, horizontal and vertical analysis of data, we examine rates of growth in key industrial indices at the Moscow Stock Exchange and predict their future behavior. Results As part of this research, we devised forecasting tools for examining the financial market and key mechanisms for raising investment resources from the financial sector.

Conclusions and Relevance The research is of scientific value since it explores internal mechanisms for raising investment, which result from a mathematical framework for market forecasting. The resultant forecasting tools are recommendable to use to get a deeper understanding of the financial market trends and key mechanisms for attracting investment resources from the financial sector.
\end{abstract}

The editor-in-charge of this article was Irina M. Vechkanova Authorized translation by Irina M. Vechkanova

Operations in the securities market are indispensable of forecasting. Securities market actors can gain yields only if their foresee how the market behaves in

${ }^{\dagger}$ For the source article, please refer to: Ильясов Р.Х., Куразова Д.А. Прогнозирование конъюнктуры финансового рынка и оценка его влияния на развитие промышленности. Финансы и кредит. 2017. T. 23. № 43. С. 2575-2591. URL: https://doi.org/10.24891/fc.23.43.2575 the future [1]. Various methods and models are used to forecast future fluctuations of market prices. In this research, we focus on forecasting of key industrial indicators since they strongly influence growth rates of industries and national GDP [2, 3]. Incidentally, the financial market trends depends on the amount of 
investment resources in the country ${ }^{1}$. We review trends in investments of economic agents and principal sectoral indices of the Moscow Exchange (MICEX) ${ }^{2}$ (Table 1).

According to Table 1, absolute values of total investment in fixed capital rose. Furthermore, financial investment of corporations increased too, with the exception of the year 2011 when financial investment dropped. The manner of industrial indices' movements show that increased investment, in fact, had a positive effect in the oil and gas sector (MICEX O\&G has been growing throughout the entire period), chemistry and chemical products (except for 2013, MICEX CHM grows). The consumer sector and trade are stagnating (MICEX CGS shows an insignificant growth, but it fell in 2011 and 2014). Metals, mining and machine building develop sluggishly (MICEX M\&M, MICEX MNF have been growing for three years and falling within the same time down to previous levels). Power engineering faces the toughest situation (In 2015 MICEX PWR was five times lower than in 2009) [4].

Having analyzed the way investment in the Russian economy changes and the securities market behaves with respect to certain sectors, we confirm an unstable inflow of investment. Such important sectors as machine building, mining, metal working and power engineering have no investment at all. Having evaluated growth rates of certain sectors statistically and analyzed the foreign trade structure, we found out that many sectors demonstrate negative trends in growth rates and export of goods to the global markets. Energy resources account for the highest export share, while import is represented with machines and equipment, food. Thus, despite the existing and effective import substitution programs, the Russian economy still depends on foreign products.

In this article, we try forecasting flows of the Russian securities pertaining to industrial enterprises and use

\footnotetext{
${ }^{1}$ Obukhova S.V., Fedotova G.V., Obukhova S.V., Fedotova G.V. [Investment attractiveness of the regions in the Southern Federal District]. Instituty i mekhanizmy innovatsionnogo razvitiya: mirovoi opyt $i$ rossiiskaya praktika: materialy 3i nauchnoi konferentsii [Proc. 3rd Sci. Conf. Institutions and Mechanisms for Innovative Development: Global Expertise and Russian Practices]. Kursk, SWSU Publ., 2013, pp. 220-222.

${ }^{2}$ Sectoral indices constitute price indices of the most marketable stocks of the Russian issuers as weighted in line with the market capitalization. For more detail please refer to the Moscow Exchange. URL: http://www.moex.com/ru/index/MICEXO\%26G (In Russ.)
}

well-known statistical models [5]. Before going on to make our own forecast, we review what macroeconomic situation the Bank of Russia predicts from 2016 to 2018 in its annual report, Key Areas of the Uniform Monetary Policy for 2016, 2017 and 2018.

Outlining its macroeconomic scenarios of the national economic development, the Bank of Russia assumes that foreign economic conditions will change and the economic policy of the State will be influential. The key interest rate is the principal tool the Bank of Russia uses to regulate the domestic financial market. The key interest rate has been demonstrating a downward trend for the recent years (down to 11 percent). This favorably boosts investment in the economy. However, the key interest rate remains quite high as compared with other countries (Fig. 1).

As seen in Fig. 1, Russia has one of the highest key interest rates among other BRICS countries, except for Brazil. The high interest rate obstructs the inflow of investment in fixed assets and dynamic development of various manufacturing sectors [6].

From perspectives of the Bank of Russia, the current situation in the financial market is complicated and hard to predict. However, the future economic policy is difficult to plan without as much reasonable and sound forecast of global markets as possible. The oil price is the principal external factor that strongly affects the certainty of forecasts [7]. Assuming high volatility and uncertainty of the factor, the Bank of Russia anticipates the national economy to follow three scenarios below:

1) baseline scenario implies that the average annual level of the oil price remain about USD 50 a barrel throughout a three year period;

2) optimistic scenario foresees a gradual growth in the average annual level of the Urals oil price up to USD 70-80 a barrel in 2018;

3) risky scenario envisages that the average annual level of the oil price perseveres with USD 40 a barrel within 2016-2018.

The geopolitical situation, armed conflicts in various countries and Russia's attitude to them are other factors that influence global economy, along with the oil price [8]. 
The EU and U.S. economic sanctions seriously affect the development of the Russian financial market and economy. As the Bank of Russia predicts, those factors will persevere until 2018. Financial sanctions will also prevent the Russian banks from entering the global market of interbank lending by setting up higher interest rates for the Russian borrowers. Russia sees the advent of expensive money. This will not have a positive effect on monetization.

The 2016-2018 budgetary policy of the Russian Government is one of the internal influential factors. Adhering to the moderately conservative budgetary policy, curbing a growth in natural monopolies' tariffs, adjusting wages and retirement benefits, it will be possible to set off a slump in the foreign currency portion of budgetary revenue. Such actions will calm down inflationary expectations of the public, thus naturally reducing the key interest rate of the Bank of Russia. If the key interest rate is more convergent with the refinance rate, it will increase the percentage of repaid loans [9].

Hence, key forecast parameters of the Bank of Russia looks quite modest for a mid run, but demonstrate a positive trend (Table 2).

The Bank of Russia releases quite restrained forecasts on oil prices since baseline scenarios imply USD 50 a barrel as the oil price benchmark. This is the bottom threshold, which enables the Russian economy to go on without a dramatic drop. Growth is projected through such criteria as GDP, money supply, loans, consumer demand [10].

The macroeconomic situation is complicated and hard to predict in line with the regulator's data. It is hard to foresee the securities market behavior ${ }^{3}$. However, we try to forecast the development of industry-specific segments of the Russian securities market for a mid run

\footnotetext{
${ }^{3}$ Obukhov S.V., Fedotova G.V. [Efficiency of conventional portfolio strategies in the current conditions of the Russian market]. Politika sovremennykh sotsial'no-ekonomicheskikh system: materialy I vserossiiskoi nauchno-prakticheskoi konferentsii [Proc. Sci. Conf. Policy of Contemporary Socio-Economic Systems]. Volgograd, Institute of Management Publ., 2015, pp. 172-175; Fedotova G.V., Tychina A.V. [Evaluating the situation in the global market of resources]. Aktual'nye problemy razvitiya khozyaistvuyushchikh sub"ektov, territorii I sistem regional'nogo I munitsipal'nogo upravleniya. Vypusk 2: materialy XI mezhdunarodnoi nauchno-prakticheskoi konferentsii [Proc. 11th Int. Sci. Conf. Current issues of Development of Economic Entities, Territories and Systems of Regional and Municipal Administration. Issue 2]. Kursk, SWSU Publ., 2016, pp. 173-176.
}

until 2018. More long-term forecasts are not reasonable from reliability perspectives due to the complicated geopolitical situation, surge in energy prices in global markets. For purposes of forecast and respective models, we choose six sectoral indicators, such as MICEX O\&G, MICEX CGS, MICEX CHM, MICEX M\&M, MICEX MNF, MICEX PWR and their values for the recent eight years [11].

For forecasting purposes, we make up a table combining factual and estimated data. To assess the trendline equation coefficients (the pattern that mathematically and graphically describes an increase or decrease in trends), we use built-in functions of the EXCEL Analysis Toolpak. In this case, we build a trend line, with the timing factor being an influence indicator and the index value being variable [12-14].

Please find below the trendline equation:

$$
Y(t)=a_{0}+a_{1} \cdot t+\varepsilon,
$$

where $a_{0}$ is the zero coefficient of regression with the time factor of 0 ;

$a_{1}$ is the coefficient reflecting to what extent the time factor influences the dependent one;

$\varepsilon$ is a random components, standard error of the model;

$Y$ denotes real and factual values;

$t$ is an influence factor, time.

The securities market trends can be forecast by setting a forecast model, i.e. make trendline equation on the basis of series trends [15].

According to estimates in Table 2, the forecast trend drifts upward, meaning that the market of oil and gas enterprises' securities will be growing, thus instigating an increase in the sector. Likewise, forecast models of the following five sectoral indices are constructed (Table 3-5).

As per the forecast in Table 5, the consumer sector index trendline is moving upward, thus signifying a growth in the consumer demand and trade turnover rates.

Securities market index in chemical and petrochemical production demonstrates an upward trend. It explains 
why export of respective products gets more intense (Table 6).

High volatility of quotes is typical of the securities market in metallurgy and mining. They spike and slump. However, predictable upward movements in the market contributes to its qualitative growth. Nevertheless, the model reliability of 0.047 is insufficient for us to draw upon it (Table 7).

The index of the machine building industry is rather chaotic and difficult to predict. High volatility and drastic drop in quotes for machine building enterprises' securities signify stagnation processes and a decline in the industry. This market has a neutral forecast, without rise and fall being anticipated. The forecast model is very unreliable, i.e. 0.0001 . So, the market is almost unpredictable (Table 8).

The securities market of energy companies continues declining almost all the time. This trend is expected to persevere within the coming two years. Thus, production in the sector will not increase or decrease considerably. However, the low reliability of the model raises our doubts about its respective forecasts (Table 9).

Following the analysis, we formed forecast models reflecting the development of the Russian market of industrial issuers' securities.

$$
\left(\begin{array}{l}
Y=1386,72+411,292 \cdot t \\
Y=2 \quad 142,551786+592,9457143 \cdot t \\
Y=1302,788571+1331,730595 \cdot t \\
Y=1302,788571+1331,730595 \cdot t \\
Y=3 \quad 056,918929+118,1260714 \cdot t \\
Y=1 \quad 662,139286+3,478214286 \cdot t \\
Y=2540,608929+185,1639286 \cdot t
\end{array}\right.
$$

Currently, it is incidentally important to forecast the Industrial Production Index (IPI). In practice, the real economy and IPP in particular are influenced by security market developments.

We hypothesize that IPI can be predicted through the nonlinear mathematical model, i.e. perceptron based on artificial intelligence. The forecast error will not exceed five percent indeed. We use inputs below to form the artificial intelligence system: trading volume in the stock market (billion RUB), trading volume in the derivatives market (billion RUB), trading volume in the foreign exchange market (billion RUB), interest rate set by the Central Bank of Russia (\%), USD exchange rate (RUB), Brent oil price (USD), GDP (billion RUB), MICEX index. IPI is to be inferred.

Please refer to Table 1 for inputs of the artificial intelligence system. They are presented as they develop, proceeding from the Deductor platform.

It seems reasonable to form the neural model as a perceptron with a single hidden layer. The neural network is trained with the backward propagation of errors (Table 10). The sigmoid function is used to activate the neuron (Fig. 2).

As researches show, estimated IPI insignificantly deviates from its factual values. It is visualized in Fig. 3.

The error contribution does not exceed 5 percent in each range of values (Fig. 4).

Drawing upon the what-if analysis embedded in the neural network, we can forecast IPI for the following period. Other things being equal while inputs change, we can estimate IPI. Let us try out the following values in the model: trading volume in the stock market RUB 311,180 billion, trading volume in the derivatives market - RUB 115,271 billion, trading volume in the foreign exchange market - RUB 329,954 billion, interest rate of the Central Bank of Russia - 9\%, USD exchange rate - RUB 57.46, Brent oil price - USD 58.09, MICEX index - 2,084.77, GDP - RUB 61,097.5. Then IPI is forecast to be 103.8675 , assuming that the factual IPI was 101.3 in 2016 (Fig. 5).

Hence we can conclude that:

- first, the use of artificial intelligence systems are of significance nowadays;

- second, we verify the hypothesis stating that the IPI can be forecast through the nonlinear mathematical model, that is a perceptron based on artificial intelligence, with the error not exceeding five percent;

- third, according to the neural network-based forecast, IPI accounts for 103.8675, that is higher than the factual one (2016: 101.3). IPI is expected to grow by 2.56 percentage points.

It is noteworthy that an analysis of quotes for the Russian issuers' securities enables us to get 
a comprehensive understanding of the current trends in an industry. Stock exchange quotations of securities and resultant stock exchange indices respond sensitively to macroeconomic developments and factors, thus having an immediate effect on trends in prices for stocks and bonds. Amendments to the domestic financial policy, measures of the Central Bank of Russia, investing activities, etc. absorb the securities market, which generates its own product, i.e. stock exchange quotations for securities $[11,16]$.

Table 1

Changes in the volume and nature of investment and sector indices in 2009-2016

\begin{tabular}{|c|c|c|c|c|c|c|c|c|}
\hline \multirow[t]{2}{*}{ Period } & \multicolumn{4}{|c|}{ Investment, billion RUB } & \multirow{2}{*}{$\begin{array}{l}\text { MICEX 0\&G, } \\
\text { RUB }\end{array}$} & \multirow[t]{2}{*}{$\uparrow \downarrow$} & \multirow{2}{*}{$\begin{array}{l}\text { MICEX CGS, } \\
\text { RUB }\end{array}$} & \multirow[t]{2}{*}{$\uparrow \downarrow$} \\
\hline & Fixed capital & $\uparrow \downarrow$ & $\begin{array}{l}\text { Financial } \\
\text { investment }\end{array}$ & $\uparrow \downarrow$ & & & & \\
\hline 12.2009 & $7,976,012.8$ & - & 22,745 & - & $2,535.43$ & - & $3,308.91$ & - \\
\hline 12.2010 & $9,152,096$ & $\uparrow$ & $41,274.8$ & $\uparrow$ & $2,981.75$ & $\uparrow$ & $6,127.99$ & $\uparrow$ \\
\hline 12.2011 & $11,035,652$ & $\uparrow$ & 66,634 & $\downarrow$ & $2,983.37$ & $\uparrow$ & $3,907.8$ & $\downarrow$ \\
\hline 12.2012 & $12,586090.4$ & $\uparrow$ & $67,724.8$ & $\uparrow$ & $3,306.49$ & $\uparrow$ & $4,973.47$ & $\uparrow$ \\
\hline 12.2013 & $13,450,238.2$ & $\uparrow$ & $72,888.5$ & $\uparrow$ & $3,491.14$ & $\uparrow$ & $6,245.95$ & $\uparrow$ \\
\hline 12.2014 & $13,902,645.3$ & $\uparrow$ & $78,604.4$ & $\uparrow$ & $3,540.17$ & $\uparrow$ & $5,460.63$ & $\downarrow$ \\
\hline 12.2015 & $14,555,902$ & $\uparrow$ & $127,113.6$ & $\uparrow$ & $4,608.88$ & $\uparrow$ & $6,804.08$ & $\uparrow$ \\
\hline 12.2016 & $14,988,907$ & $\uparrow$ & $131,113.6$ & $\uparrow$ & $5,690.32$ & $\uparrow$ & $6,781.37$ & $\downarrow$ \\
\hline \multicolumn{9}{|l|}{ Continued } \\
\hline Period & MICEX CHM, RUB & $\uparrow \downarrow$ & MICEX M\&M, RUB & $\uparrow \downarrow$ & $\begin{array}{l}\text { MICEX MNF, } \\
\text { RUB }\end{array}$ & $\uparrow \downarrow$ & $\begin{array}{l}\text { MICEX PWR, } \\
\text { RUB }\end{array}$ & $\uparrow \downarrow$ \\
\hline 12.2009 & $4,362.91$ & - & $3,610.78$ & - & $1,656.6$ & - & $2,384.25$ & $\uparrow$ \\
\hline 12.2010 & $6,275.62$ & $\uparrow$ & $5,887.72$ & $\uparrow$ & $2,881.64$ & $\uparrow$ & $3,435.32$ & $\downarrow$ \\
\hline 12.2011 & $6,936.21$ & $\uparrow$ & $3,082.65$ & $\downarrow$ & $1,715.16$ & $\downarrow$ & $2,053.02$ & $\downarrow$ \\
\hline 12.2012 & $7,839.34$ & $\uparrow$ & $2,908.55$ & $\downarrow$ & $2,004.21$ & $\uparrow$ & $1,707.42$ & $\downarrow$ \\
\hline 12.2013 & $6,468.1$ & $\downarrow$ & $2,264.99$ & $\downarrow$ & $1,930.58$ & $\downarrow$ & $1,032.39$ & $\downarrow$ \\
\hline 12.2014 & $7,745.69$ & $\uparrow$ & $3,457.62$ & $\uparrow$ & $1,027.55$ & $\downarrow$ & 797.54 & $\downarrow$ \\
\hline 12.2015 & $13,629.7$ & $\uparrow$ & $3,783.72$ & $\uparrow$ & $1,464.66$ & $\uparrow$ & 944.51 & $\uparrow$ \\
\hline 12.2016 & $14,423.8$ & $\uparrow$ & $5,536.89$ & $\uparrow$ & $1,648.94$ & $\uparrow$ & $1,984.16$ & $\uparrow$ \\
\hline
\end{tabular}

Source: Authoring, based on the Federal State Statistics Service of Russia official website data.

URL: http://www.gks.ru/wps/wcm/connect/rosstat_main/rosstat/ru/statistics/enterprise/investment/nonfinancial/; The official site of the Moscow stock exchange.URL: http://moex.com/en/index/MICEXPWR/technical/ 
Table 2

Forecast of the main economic indicators of development as estimated by the Central Bank of Russia in 2014-2018

\begin{tabular}{|c|c|c|c|c|c|c|c|c|}
\hline \multirow[t]{2}{*}{ Indicator } & \multirow{2}{*}{$\begin{array}{l}2014 \\
\text { (factual) }\end{array}$} & \multirow{2}{*}{$\begin{array}{l}2015 \\
\text { (estimate) }\end{array}$} & \multicolumn{2}{|l|}{2016} & \multicolumn{2}{|l|}{2017} & \multicolumn{2}{|l|}{2018} \\
\hline & & & Base & Optimal & Base & Optimal & Base & Optimal \\
\hline Urals oil price, USD/barrel & 98 & 52 & 50 & 60 & 50 & 70 & 50 & 75 \\
\hline $\begin{array}{l}\text { GDP, increment, percentage } \\
\text { points }\end{array}$ & 0.6 & $-(3.9-4.4)$ & $-(0.5-0.1)$ & $0-0.5$ & $0-0.1$ & $1-2$ & $2-3$ & $2.5-3.5$ \\
\hline Inflation, percent & 11.4 & $12-13$ & $5.5-6.5$ & $5.5-6.5$ & 4 & 4 & 4 & 4 \\
\hline $\begin{array}{l}\text { Money supply, increment, } \\
\text { percentage points }\end{array}$ & 2.2 & $5-8$ & $4-7$ & $8-10$ & $8-11$ & $13-16$ & $13-16$ & $13-16$ \\
\hline $\begin{array}{l}\text { Loans, increment, percentage } \\
\text { points }\end{array}$ & 25.9 & $4-7$ & $4-7$ & $7-9$ & $8-11$ & $13-16$ & $13-16$ & $13-16$ \\
\hline $\begin{array}{l}\text { Consumer demand, } \\
\text { increment, percentage points }\end{array}$ & 0.9 & $-(6.1-6.9)$ & $-(1-1.4)$ & $0-0.3$ & $-(0.7-0.3)$ & $0.8-1.5$ & $1.5-2.5$ & $2-3$ \\
\hline $\begin{array}{l}\text { Net export, increment, } \\
\text { percentage points }\end{array}$ & 29.8 & $74.5-76.5$ & $8.5-10.5$ & $1.5-3.5$ & $8.5-10.5$ & $-(1.5-3.5)$ & $-(5-7)$ & $-(14.5-16.5)$ \\
\hline
\end{tabular}

Source:Authoring, based on The Main Directions of the Uniform Monetary Policy in 2016 and the 2017-2018 period. Central Bank of Russia

Table 3

Factual data for compiling a forecast model for developing the securities market of industrial enterprises in Russia in 2009-2016

\begin{tabular}{lllllll}
\hline Date & MICEX 0\&G & MICEX CGS & MICEX CHM & MICEX M\&M & MICEX MNF & MICEX PWR \\
\hline 01.2009 & $1,218.25$ & $1,034.87$ & $1,490.77$ & $1,304.24$ & 475.3 & 744.04 \\
\hline 01.2010 & $2,567.08$ & $3,553.99$ & $4,604.25$ & $4,087.13$ & $1,740.21$ & $2,652.89$ \\
\hline 10.2011 & $3,096.82$ & $6,078.98$ & $6,742.34$ & $5,769.64$ & $2,929.58$ & $3,434.02$ \\
\hline 01.2012 & $3,187.77$ & $4,384.44$ & $7,226.58$ & $3,598.71$ & $1,931.82$ & $2,262.38$ \\
\hline 01.2013 & $3,396.21$ & $5,456.11$ & $7,995.5$ & $2,918.6$ & $2,029.63$ & $1,813.26$ \\
\hline 01.2014 & $3,422.94$ & $5,644.79$ & $6,673.67$ & $2,664.71$ & $1,772.63$ & $1,000.38$ \\
\hline 01.2015 & $4,176.82$ & $5,640.29$ & $10,330.7$ & $4,535.6$ & $1,054.38$ & 797.5 \\
\hline 01.2016 & $4,834.39$ & $6,692.99$ & $13,300.8$ & $3,829.26$ & $1,488.78$ & 954.5 \\
\hline
\end{tabular}

Source:Authoring, based on the Moscow Exchange official website data

Table 4

Forecasting the MICEX 0\&G index trends

\begin{tabular}{|c|c|c|c|c|}
\hline$t$ & Date & $\begin{array}{l}\text { MICEX 0\&G } \\
Y \text { (factual) }\end{array}$ & Trendline equation (Model) & $\begin{array}{l}\text { MICEX 0\&G } \\
Y \text { (estimate and } \\
\text { forecast) }\end{array}$ \\
\hline 1 & 01.2009 & $1,218.25$ & $a_{0}=1,386.724$ & $1,798.015$ \\
\hline 2 & 01.2010 & $2,567.08$ & $a_{1}=411.2914$ & $2,209.306$ \\
\hline 3 & 01.2011 & $3,096.82$ & $y=1,386.72+411.292 \cdot t$ & $2,620.598$ \\
\hline 4 & 01.2012 & $3,187.77$ & & $3,031.889$ \\
\hline 5 & 01.2013 & $3,396.21$ & & $3,443.181$ \\
\hline 6 & 01.2014 & $3,422.94$ & & $3,854.472$ \\
\hline 7 & 01.2015 & $4,176.82$ & & $4,265.764$ \\
\hline 8 & 01.2016 & $4,834.39$ & & $4,677.055$ \\
\hline 9 & 01.2017 & - & & $5,088.346$ \\
\hline 10 & 01.2018 & - & & $5,499.638$ \\
\hline
\end{tabular}

Source: Authoring

Please cite this article as: Il'yasov R.Kh., Kurazova D.A. Forecasting the Situation in the Financial Market and Evaluating Its Impact on the Industry Development. Digest Finance, 2018, vol. 23, iss. 1, pp. 68-80. https://doi.org/10.24891/df.23.1.68 
Table 5

Forecasting the MICEX CGS index trends

\begin{tabular}{|c|c|c|c|c|}
\hline$t$ & Date & $\begin{array}{l}\text { MICEX CGS } \\
Y \text { (factual) }\end{array}$ & Trendline equation (Model) & $\begin{array}{l}\text { MICEX CGS } \\
Y \text { (estimate and } \\
\text { forecast) }\end{array}$ \\
\hline 1 & 01.2009 & $1,034.87$ & $a_{0}=2,142.551786$ & $2,735.498$ \\
\hline 2 & 01.2010 & $3,553.99$ & $a_{1}=592.9457143$ & $3,328.443$ \\
\hline 3 & 01.2011 & $6,078.98$ & \multirow[t]{8}{*}{$y=2,142.551786+592.9457143$} & $3,921.389$ \\
\hline 4 & 01.2012 & $4,384.44$ & & $4,514.335$ \\
\hline 5 & 01.2013 & $5,456.11$ & & $5,107.28$ \\
\hline 6 & 01.2014 & $5,644.79$ & & $5,700.226$ \\
\hline 7 & 01.2015 & $5,640.29$ & & $6,293.172$ \\
\hline 8 & 01.2016 & $6,692.99$ & & $6,886.118$ \\
\hline 9 & 01.2017 & - & & $7,479.063$ \\
\hline 10 & 01.2018 & - & & $8,072.009$ \\
\hline
\end{tabular}

Source:Authoring

Table 6

Forecasting the MICEX CHM index trend

\begin{tabular}{|c|c|c|c|c|}
\hline$t$ & Date & $\begin{array}{l}\text { MICEX CHM } \\
Y \text { (factual) }\end{array}$ & Trendline equation (Model) & $\begin{array}{l}\text { MICEX CHM } \\
Y \text { (estimate and } \\
\text { forecast) }\end{array}$ \\
\hline 1 & 01.2009 & $1,490.77$ & $a_{0}=1,302.788571$ & $2,634.519$ \\
\hline 2 & 01.2010 & $4,604.25$ & $a_{1}=1,331.730595$ & $3,966.25$ \\
\hline 3 & 01.2011 & $6,742.34$ & \multirow{8}{*}{$y=1,302.788571+1,331.730595$} & $5,297.98$ \\
\hline 4 & 01.2012 & $7,226.58$ & & $6,629.711$ \\
\hline 5 & 01.2013 & $7,995.5$ & & $7,961.442$ \\
\hline 6 & 01.2014 & $6,673.67$ & & $9,293.172$ \\
\hline 7 & 01.2015 & $10,330.7$ & & $10,624.9$ \\
\hline 8 & 01.2016 & $13,300.8$ & & $11,956.63$ \\
\hline 9 & 01.2017 & - & & $13,288.36$ \\
\hline 10 & 01.2018 & - & & $14,620.09$ \\
\hline
\end{tabular}

Source: Authoring 
Table 7

Forecasting the MICEX M\&M index trends

\begin{tabular}{|c|c|c|c|c|}
\hline$t$ & Date & $\begin{array}{l}\text { MICEX M\&M } \\
Y \text { (factual) }\end{array}$ & Trendline equation (Model) & $\begin{array}{l}\text { MICEX M\&M } \\
Y \text { (estimate and } \\
\text { forecast) }\end{array}$ \\
\hline 1 & 01.2009 & $1,304.24$ & $a_{0}=3,056,918929$ & $3,175.045$ \\
\hline 2 & 01.2010 & $4,087.13$ & $a_{1}=118,1260714$ & $3,293.171$ \\
\hline 3 & 01.2011 & $5,769.64$ & \multirow[t]{8}{*}{$y=3,056,918929+118,1260714$} & $3,411.297$ \\
\hline 4 & 01.2012 & $3,598.71$ & & $3,529.423$ \\
\hline 5 & 01.2013 & $2,918.6$ & & $3,647.549$ \\
\hline 6 & 01.2014 & $2,664.71$ & & $3,765.675$ \\
\hline 7 & 01.2015 & $4,535.6$ & & $3,883.801$ \\
\hline 8 & 01.2016 & $3,829.26$ & & $4,001.928$ \\
\hline 9 & 01.2017 & - & & $4,120.054$ \\
\hline 10 & 01.2018 & - & & $4,238.18$ \\
\hline
\end{tabular}

Source:Authoring

Table 8

Forecasting the MICEX MNF index trends

\begin{tabular}{|c|c|c|c|c|}
\hline$t$ & Date & $\begin{array}{l}\text { MICEX MNF } \\
Y \text { (factual) }\end{array}$ & Trendline equation (Model) & $\begin{array}{l}\text { MICEX MNF } \\
Y \text { (estimate and } \\
\text { forecast) }\end{array}$ \\
\hline 1 & 01.2009 & 475.3 & $a_{0}=1,662.139286$ & $1,665.618$ \\
\hline 2 & 01.2010 & $1,740.21$ & $a_{1}=3.478214286$ & $1,669.096$ \\
\hline 3 & 01.2011 & $2,929.58$ & \multirow{8}{*}{$y=1,662 \cdot 139286+3.478214286$} & $1,672.574$ \\
\hline 4 & 01.2012 & $1,931.82$ & & $1,676.052$ \\
\hline 5 & 01.2013 & $2,029.63$ & & $1,679.53$ \\
\hline 6 & 01.2014 & $1,772.63$ & & $1,683.009$ \\
\hline 7 & 01.2015 & $1,054.38$ & & $1,686.487$ \\
\hline 8 & 01.2016 & $1,488.78$ & & $1,689.965$ \\
\hline 9 & 01.2017 & - & & $1,689.965$ \\
\hline 10 & 01.2018 & - & & $1,696.921$ \\
\hline
\end{tabular}

Source: Authoring 
Table 9

Forecasting the MICEX PWR index trends

\begin{tabular}{|c|c|c|c|c|}
\hline$t$ & Date & $\begin{array}{l}\text { MICEX PWR } \\
Y \text { (factual) }\end{array}$ & Trendline equation (Model) & $\begin{array}{l}\text { MICEX PWR } \\
Y \text { (estimate and } \\
\text { forecast) }\end{array}$ \\
\hline 1 & 01.2009 & 744.04 & $a_{0}=2,540.608929$ & $2,355.445$ \\
\hline 2 & 01.2010 & $2,652.89$ & $a_{1}=-185.1639286$ & $2,170.281$ \\
\hline 3 & 01.2011 & $3,434.02$ & \multirow{8}{*}{$y=2,540.608929+-185.1639286$} & $1,985.117$ \\
\hline 4 & 01.2012 & $2,262.38$ & & $1,799.953$ \\
\hline 5 & 01.2013 & $1,813.26$ & & $1,614.789$ \\
\hline 6 & 01.2014 & $1,000.38$ & & $1,429.625$ \\
\hline 7 & 01.2015 & 797.5 & & $1,244.461$ \\
\hline 8 & 01.2016 & 954.5 & & $1,059.298$ \\
\hline 9 & 01.2017 & - & & 874.1336 \\
\hline 10 & 01.2018 & - & & 688.9696 \\
\hline
\end{tabular}

Source:Authoring

Table 10

The training set

\begin{tabular}{llllllllll}
\hline Year & $\begin{array}{l}\text { Stock market, } \\
\text { trading volume, } \\
\text { billion RUB }\end{array}$ & $\begin{array}{l}\text { Derivatives } \\
\text { market, billion } \\
\text { RUB }\end{array}$ & $\begin{array}{l}\text { Foreign } \\
\text { exchange } \\
\text { market, billion } \\
\text { RUB }\end{array}$ & $\begin{array}{l}\text { Interest } \\
\text { rate of } \\
\text { the } \\
\text { Central } \\
\text { Bank of } \\
\text { Russia, } \%\end{array}$ & $\begin{array}{l}\text { USD } \\
\text { rate }\end{array}$ & $\begin{array}{l}\text { Brent } \\
\text { oil, USD }\end{array}$ & $\begin{array}{l}\text { MICEX } \\
\text { index }\end{array}$ & $\begin{array}{l}\text { GDP, } \\
\text { billion RUB }\end{array}$ & IPI \\
\hline 2016 & 311,180 & 115,271 & 329,954 & 10.5 & 59.62 & 54.89 & $2,195.07$ & $61,097.5$ & 101.3 \\
\hline 2015 & 197,882 & 93,691 & 310,837 & 17 & 77.93 & 39.02 & $1,743.14$ & $60,687.1$ & 96.6 \\
\hline 2014 & 204,018 & 61,601 & 228,546 & 10.5 & 33.93 & 63.43 & $1,470.57$ & $63,049.2$ & 101.7 \\
\hline 2013 & 228,401 & 48,415 & 156,016 & 8.25 & 30.21 & 110.54 & $1,475.4$ & $62,581.9$ & 100.4 \\
\hline 2012 & 182,670 & 49,969 & 116,980 & 8.25 & 31.18 & 108.78 & $1,460.44$ & $61,791.6$ & 103.4 \\
\hline 2011 & 92,540 & 55,345 & 87,015 & 8.25 & 29.99 & 107.53 & $1,411.55$ & $59,698.1$ & 105 \\
\hline 2010 & 64,030 & 29,350 & 79,519 & 8 & 29.83 & 92.15 & $1,663.62$ & $46,321.8$ & 107.3 \\
\hline 2009 & 42,285 & 14,169 & 95,999 & 9 & 32.49 & 75.28 & $1,342.97$ & $38,807.2$ & 89.3 \\
\hline
\end{tabular}

Source:Authoring

Figure 1

Key rates in the BRICS, EU countries, and the USA

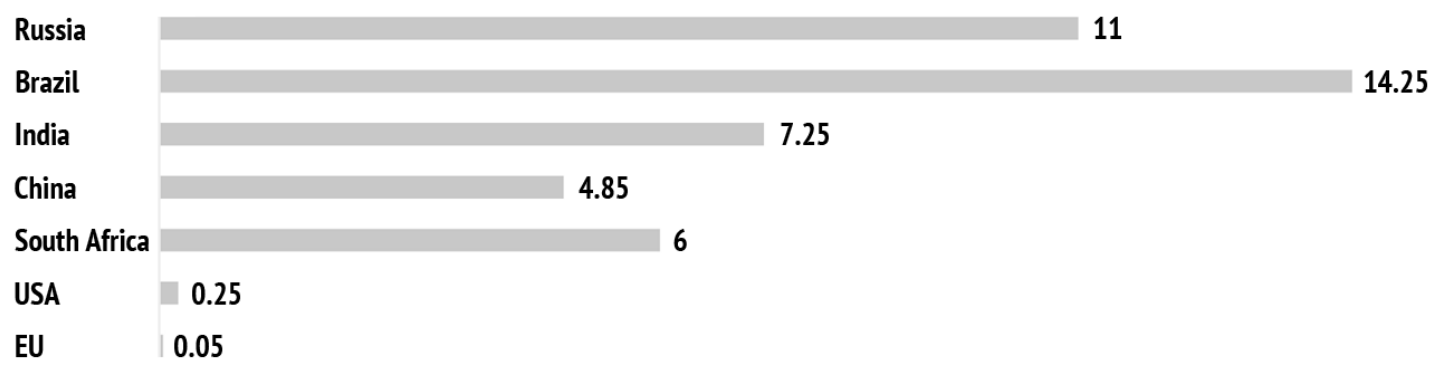

Source: Authoring, based on The Main Directions of the Uniform Monetary Policy in 2016 and the 2017-2018 period 


\section{Figure 2}

The neural network graph - perceptron

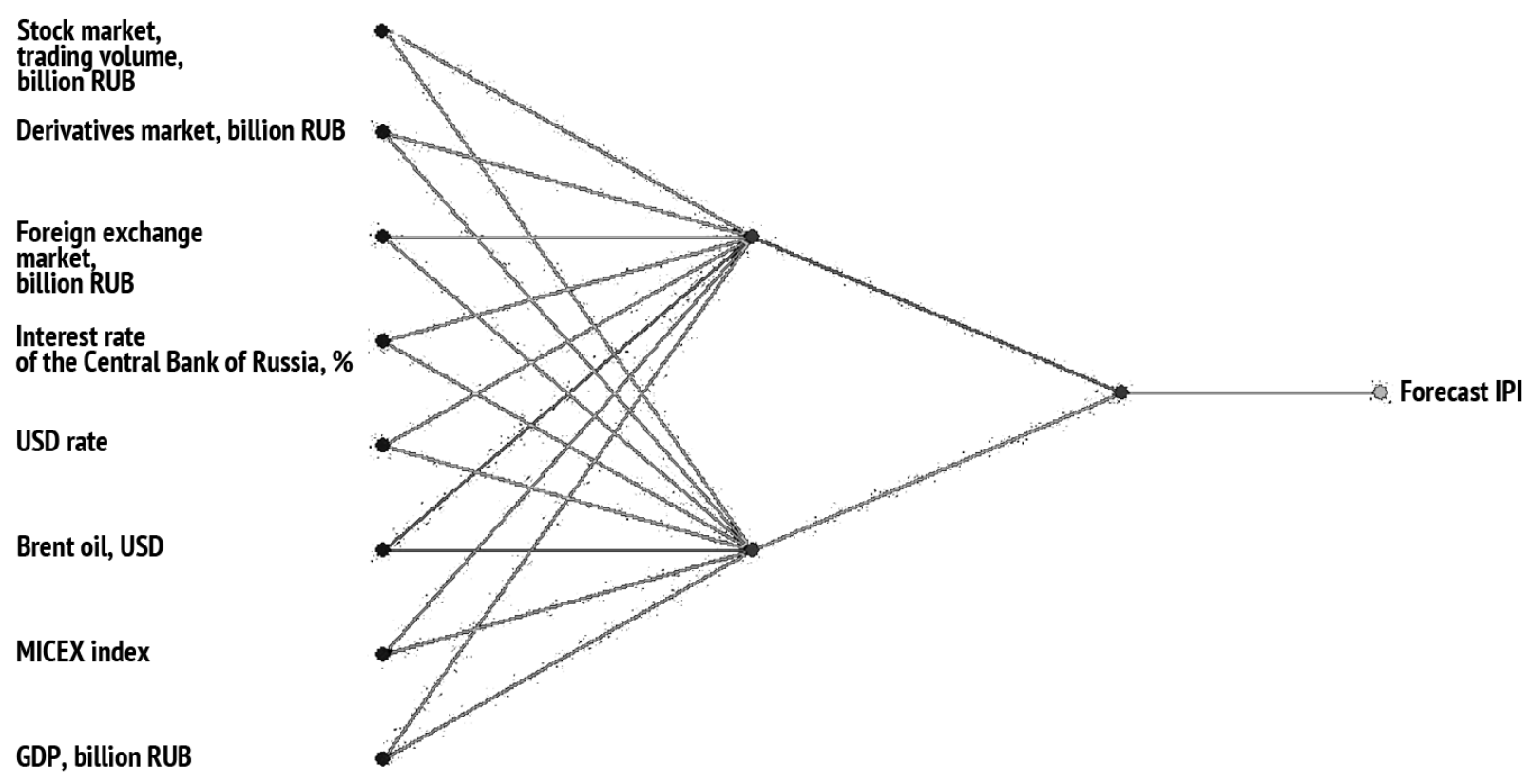

Source:Authoring

\section{Figure 3}

The diagram of factual and forecast values

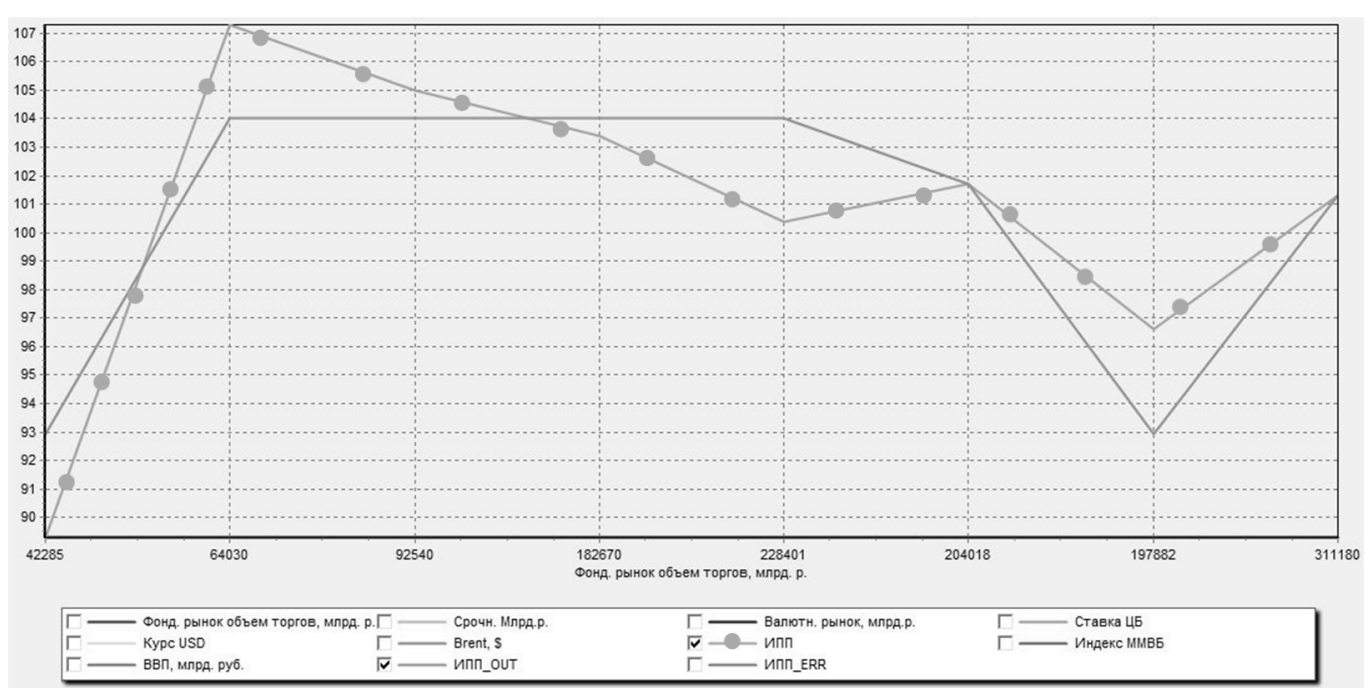

Source:Authoring 


\section{Figure 4}

The error contribution of the forecast inferred through the neural network

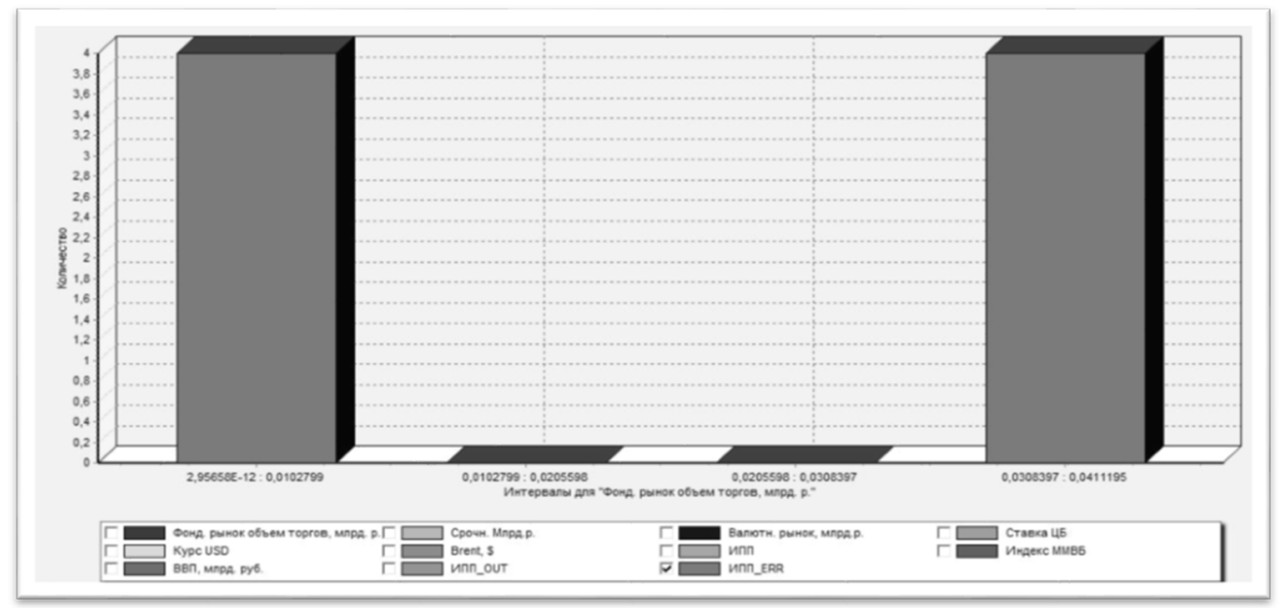

Source: Authoring

\section{Figure 5}

The forecast value of the neural network for 2017

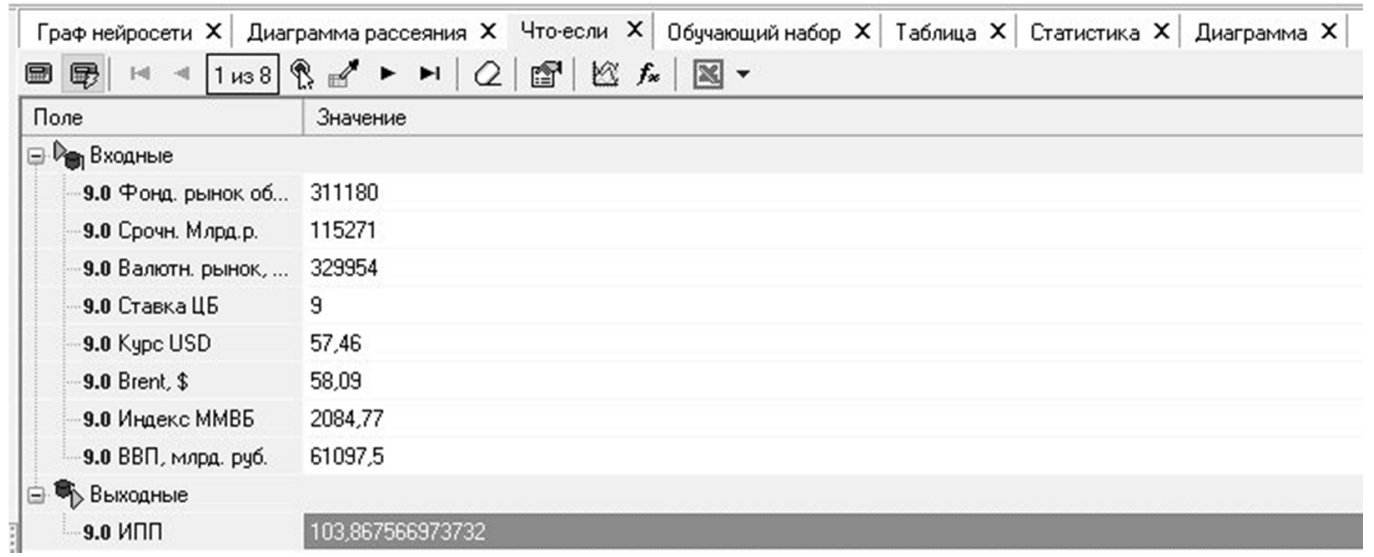

\section{Source:Authoring}




\section{References}

1. Shishulin S.S. [Comparative analysis of the rate of development of industrial production of Russia and the European union]. Ekonomicheskie nauki = Economic Sciences, 2015, no. 8, pp. 99-103.

URL: http://ecsn.ru/files/pdf/201508/201508_99.pdf (In Russ.)

2. Golovin K.V., Andrukhova S.V., Klevtsova M.G. [The research of dependence of Russian economy on the condition of petroleum and financial markets: The financial analysts' opinion review]. Innovatsionnaya ekonomika: perspektivy razvitiya i sovershenstvovaniya, 2017, no. 1, pp. 69-75. (In Russ.)

3. Mitrofanov V.I. [Analysis of the interconnection of Russian stock market with global financial market conditions]. Ekonomika i predprinimatel'stvo = Journal of Economy and Entrepreneurship, 2015, no. 6-2, pp. 59-63. (In Russ.)

4. Aleksandrov A.V., Gogua L.S. [Methods and models of evaluation of conditions in the financial market]. Ekonomika i predprinimatel'stvo = Journal of Economy and Entrepreneurship, 2017, no. 1, pp. 849-852. (In Russ.)

5. Mitrofanov V.I. [Econometric research of the impact of the global financial market conditions on the index RTS oil and gas]. Statistika i ekonomika = Statistics and Economics, 2014, no. 6-2, pp. 435-441.

URL: https://cyberleninka.ru/article/n/ekonometricheskoe-issledovanie-vliyaniya-konyunktury-mirovogofinansovogo-rynka-na-dinamiku-indeksa-rts-nefti-i-gaza (In Russ.)

6. Bondarev N.S. [Conjuncture of the Australian financial market: Analysis and comparison it with the Russian]. Biznes i obshchestvo, 2015, no. 4. URL: http://busines-society.ru/2015/num-4-8/18_bondarev.pdf (In Russ.)

7. Fedotova G.V., Obukhova S.V. [Portfolio management strategies for optimization of corporate financial flows under the European Union sanctions]. Finansovaya analitika: problemy i resheniya = Financial Analytics: Science and Experience, 2015, no. 19, pp. 30-40.

URL: https://cyberleninka.ru/article/n/portfelnye-strategii-optimizatsii-korporativnyh-finansovyh-potokov-vusloviyah-sanktsiy-evropeyskogo-soyuza (In Russ.)

8. Polteva T.V. [Financial market research as an aspect of risk-management at the enterprise]. Molodoi uchenyi $=$ Young Scientist, 2016, no. 29, pp. 475-477. (In Russ.)

9. Dubinina E.D., Fedotova G.V. [Financial crisis and its reasons]. Upravlenie. Biznes. Vlast', 2015, no. 3, pp. 39-43. (In Russ.)

10. Fedotova G.V., Obukhova S.V. [An evaluation of the situation in the Russian stock market during the global crisis]. Finansovaya analitika: problemy i resheniya = Financial Analytics: Science and Experience, 2016, no. 13, pp. 2-15. URL: https://cyberleninka.ru/article/n/otsenka-situatsii-na-rossiyskom-fondovom-rynke-v-usloviyahglobalnogo-krizisa (In Russ.)

11. Plotnikov V., Fedotova G., Popkova E. et al. Harmonization of Strategic Planning Indicators of Territories' Socioeconomic Growth. Regional and Sectoral Economic Studies, 2015, vol. 15-2, pp. 105-114. URL: http://www.usc.es/economet/journals2/eers/eers1527.pdf

12. Modigliani F., Miller M. The Cost of Capital, Corporation Finance and Theory of Investment. The American Economic Review, 1958, vol. 48, no. 3, pp. 261-297. URL: http://lib.cufe.edu.cn/upload_files/other/3_20140507105115_01.pdf

13. Markowitz H.M. Portfolio Selection: Efficient Diversification of Investments. Oxford, N.Y., Blackwell, 1991, 384 p. 
14. Sharpe W.F. Capital Asset Price: A Theory of Market Equilibrium under Conditions of Risk. The Journal of Finance, 1964, vol. 19, iss. 3, pp. 425-442.

URL: http://links.jstor.org/sici?sici=0022-1082\%28196409\%2919\%3A3\%3C425\%3ACAPATO\%3E2.0.CO\%3B2-O

15. Sazonov S.P., Fedotova G.V., Perekrestova L.V., Kozenko Y.A. Anti-crisis Budget Policy of Russia in 2016-2018. In: Russia and the European Union: Development and Perspectives. Springer, 2017, pp. 81-88.

16. Tobin J. The Theory of Portfolio Selection. Theory of Interest Rates. Ed. by F.H. Hahn, F.P.R. Brechling. London, MacMillan, 1965, pp. 3-51.

\section{Conflict-of-interest notification}

We, the authors of this article, bindingly and explicitly declare of the partial and total lack of actual or potential conflict of interest with any other third party whatsoever, which may arise as a result of the publication of this article. This statement relates to the study, data collection and interpretation, writing and preparation of the article, and the decision to submit the manuscript for publication. 